\title{
Energy Consumption in Residential Buildings: Comparison between Three Different Building Styles
}

\author{
Mohamed A. Umbarek ${ }^{1}$, Samah K. Alghoul ${ }^{1} \&$ Elhadi I. Dekam ${ }^{1}$ \\ ${ }^{1}$ Mechanical and Industrial Engineering Department, University of Tripoli, Tripoli, Libya \\ Correspondence: Samah Alghoul, L113, Mechanical and Industrial Department, University of Tripoli, Tripoli, \\ Libya. Tel: 218-927-800-074. E-mail: s.alghoul@uot.edu.ly
}

Received: March 1, 2020 Accepted: March 15, 2020 Online Published: March 21, 2020

\begin{abstract}
More than one-third of the electricity generated in the world is being consumed in the residential sector. This study aims to model, simulate, and estimate electrical energy consumption in three different building styles. That is in order to compare and contrast energy consumption categories and their related social and architectural aspects for an unaddressed region that have its particular weather conditions and its special social and environmental aspects. The simulation is done by detailed modeling of the buildings using EnergyPlus. The results demonstrate that water heating systems account for almost one-fifth of the annual energy consumption. Cooling loads were found to be more than 5 times the heating loads. The peak of energy consumption was recorded to be in July, while the lowermost recorded in April and in November. The Apartment style requires the lowest annual energy consumption by an amount of $10 \mathrm{kWh} / \mathrm{m}^{2}$ per person followed by the Duplex house with $13 \mathrm{kWh} / \mathrm{m}^{2}$ per person, while the Single-Story house comes with the highest energy consumption of $18 \mathrm{kWh} / \mathrm{m}^{2}$ per person. These represent local power consumption of 69,79 , and $90 \mathrm{kWh} / \mathrm{m}^{2}$, respectively. On average, the water heating, space cooling, plus interior lights consume about $60 \%$ of total energy requirements with a mostly equal share for each, while the equipment has the maximum share of $35 \%$ of the total, leaving about $5 \%$ for the rest. The results of this study may be used as a reference line in the future for the calculations of energy savings in similar regions.
\end{abstract}

Keywords: residential buildings, buildings performance, energy consumption, energy benchmarks, energyplus simulation

\section{Introduction}

Locally and internationally, buildings are responsible for consuming considerable amounts of energy. Locally and Internationally, heating, cooling, and ventilation account for one-fifth to one-third of total energy consumption in residential buildings [1,2]. The efficient use of energy will save the available energy resources for the next generations. The connection between the increased $\mathrm{CO} 2$ release to the atmosphere and the use of energy is another motive to render a more efficient energy usage, and lower the total energy demand. Many types of research have been devoted to analyzing the energy performance of the buildings related to the residential sector. Building energy efficiency and performance topics were expanded via investigations of the existing actual buildings and computational models [3,4].

Simulation-based building performance allows detailed assessment of energy consumption in buildings, to analyze the energy performance which depends on many factors. These factors include construction elements, material properties, lights, HVAC systems, and occupants, amongst others. The influence of each factor can be examined extensively and systematically utilizing a dynamic energy simulation tool such as EnergyPlus [5]. EnergyPlus allows flexibility of the building's energy modeling and the use of different construction elements, material properties, lights, HVAC systems, and occupants. It also allows the modeling of a wide range of renewable technologies and other energy systems.

A significant amount of conducted research, either theoretical, statistical or experimental, [6-9] has been focusing on the subject of energy saving, the use of efficient energy, energy performance in buildings, Net-Zero Energy Building and sustainable energy. In order to perform such studies benchmarks must be established. Umbarek [10] conducted an M. Sc. Degree Thesis related to the determination of energy benchmarks concerning residential buildings in Libya. This thesis is the base of the present paper.

This paper develops reference models for residential buildings in Libya. The reference models are created by assigning the architecture frame and energy characteristics of three actual commonly used local building styles. 
The main objective is to achieve an estimation of energy consumption of the considered three residential building styles. This will be done by modeling the buildings with different functions based on the varying demographics of tenants and by estimation of the energy consumption per meter square and capita. The results of this study may be used as a reference line in the future for the calculations of energy savings in similar regions.

\section{Methodology}

The methodology is represented in several stages. It starts with the selection of the most common building styles. Followed by the collection of the related data that affect the energy consumption, including site data, orientation, areas, volumes, materials, equipment, lighting, people, water usage, and nature of the surroundings. Then the buildings are modeled in 3-D sketches. In the next step, the model is simulated by the EnergyPlus software where different loads including heating and cooling loads are to be achieved. The monthly and annual energy consumption are determined for each building style. The comparison is to be made for different styles and the average energy consumption is to be identified. More details about modeling using EnergyPlus and OpenStudio are presented widely in the literature $[3,7,10,11]$.

\section{Case Studies}

In this study, three different residential buildings with different styles were selected as case studies at different sites but in the same city of Tripoli. Each building is well defined by gathering information about building description, dimensions, orientation, envelope composition and materials, windows to wall ratio, occupation, equipment, light, different schedules, and hot water use profile. The selected buildings largely represent the styles and designs of residential buildings in Libya.

Table 1 includes the main information about the buildings. The three buildings have a similar structure and accessory components, such as walls, roofs, floors, doors, and windows. These structures and accessory components are commonly used in the Libyan residential buildings.

Table 1. Specifications of the three buildings.

\begin{tabular}{llll}
\hline Description & Building No (1) & Building No (2) & Building No (3) \\
\hline Building type & Single story house & Duplex house & Apartment \\
Location & Tripoli, Libya & Tripoli, Libya & Tripoli, Libya \\
Latitude & $32^{\circ} 53^{\prime} \mathrm{N}, 13^{\circ} 10^{\prime} \mathrm{E}$ & $32^{\circ} 53^{\prime} \mathrm{N}, 13^{\circ} 10^{\prime} \mathrm{E}$ & $32^{\circ} 53^{\prime} \mathrm{N}, 13^{\circ} 10^{\prime} \mathrm{E}$ \\
Elevation & $20 \mathrm{~m}$ above sea level & $20 \mathrm{~m}$ above sea level & $20 \mathrm{~m}$ above sea level \\
Year of construction & 1970 's & $2000^{\prime} \mathrm{s}$ & $2000^{\prime} \mathrm{s}$ \\
Total floor area & $153.72 \mathrm{~m}^{2}$ & $391.03 \mathrm{~m}^{2}$ & $191.55 \mathrm{~m}^{2}$ \\
Windows to wall ratio $\%$ & 9.19 & 4.14 & 8.75 \\
Number of floors & 1 & 2 & 1 \\
Facing orientation & South & North & North \\
Number of people & 5 & 6 & 7 \\
Number of people & 5 & 6 & 7 \\
No. of used Equipment & 14 & 17 & 12 \\
\hline
\end{tabular}

One of the important modeling steps is to draw a detailed isometric view for the selected building style, using the Sketchup software package with Open Studio, showing sides, roofs, dimensions, and orientations. Figure 1 shows isometric views for the considered three building styles. The designed main entrance to the building No 1 is facing the North-west direction, with a facade of about $10.6 \mathrm{~m}$. It is located in the Suaq AL Gumaa area. The second building is a modern design built in 2000, and it is located in the El-Kreimeya area, with the main entrance facing north. The third building is located at Suaq AL Gumma. It is an apartment in a multi-story building with a modern design built-in 2000. These three buildings mostly have the same type of building construction and materials. The overall wall heat transfer coefficient $\mathrm{U}=1.24 \mathrm{~W} / \mathrm{m} 2 . \mathrm{K}$. Windows, doors, lighting, and appliances are well defined elsewhere [10]. 


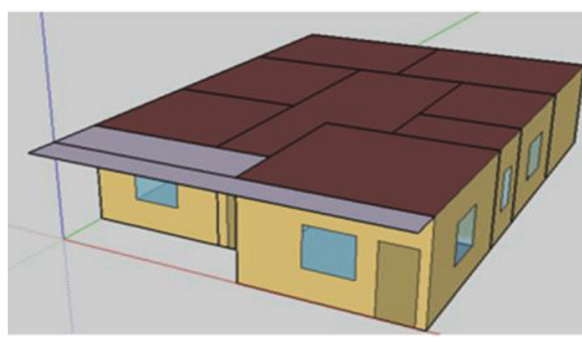

Building \# 1: Single story house

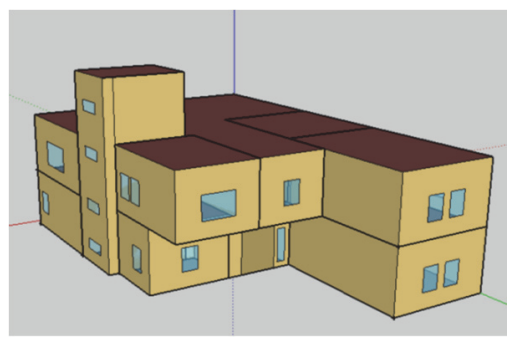

Building \# 2: Duplex house

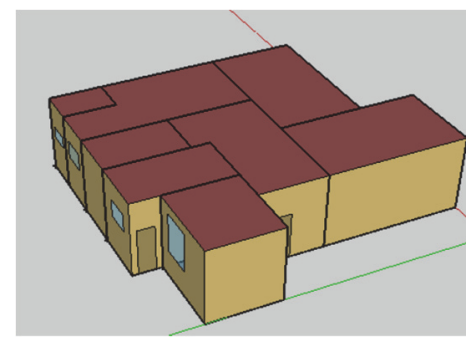

Building \# 3: Apartment

Figure 1. Sketch Up views of the buildings

\section{Modeling of Hot Water System}

The hot water usage has a considerable load effect on the overall energy consumption in residential buildings. The amount of energy consumed in providing the required hot water varies according to the behavior of the people and their lifestyle in addition to the set point temperature and weather conditions. Each building of the three styles is equipped with a service for the water heating system. The system consists of a water pump and electric water heater along with the piping connections and controller.

The water mains temperature was the same for the three buildings and assumed to vary around the year. It is obtained using a correlation that was developed by Craig Christensen and Jay Burch [12]. The water mains temperature is a function of ambient temperature and the maximum temperature difference for the selected location. As shown in Figure 2, the temperature profile mostly takes the sine wave shape with a peak of $28.5^{\circ} \mathrm{C}$ as expected in the summer season while the low temperature of $18.5^{\circ} \mathrm{C}$ occurs in the winter season.

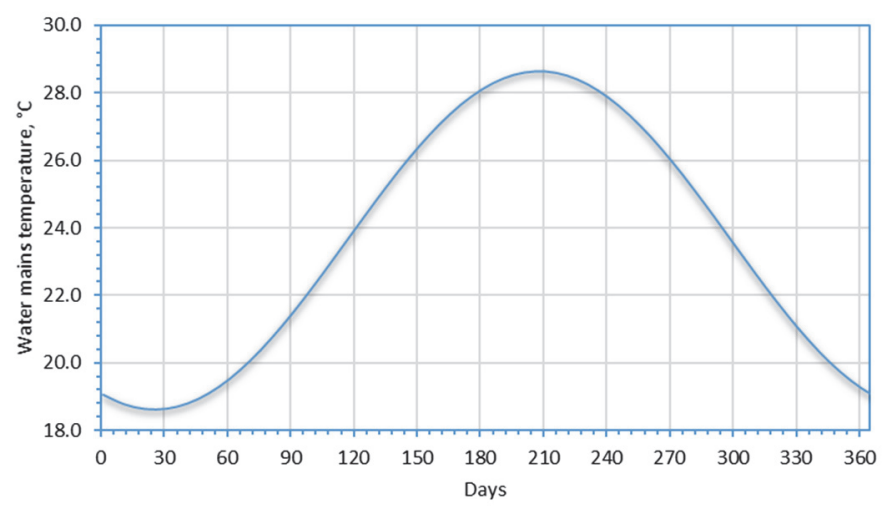

Figure 2. Water mains temperature

The hot water load pattern, which simulates the hot water consumption during the day and around the year, is shown in Figure 3 [13]. The peak demand is indicated to be at 8:00 AM while the least demand is at late night between 100 and 5:00 AM. On average, the demand never diminished and it is required around the whole day. 


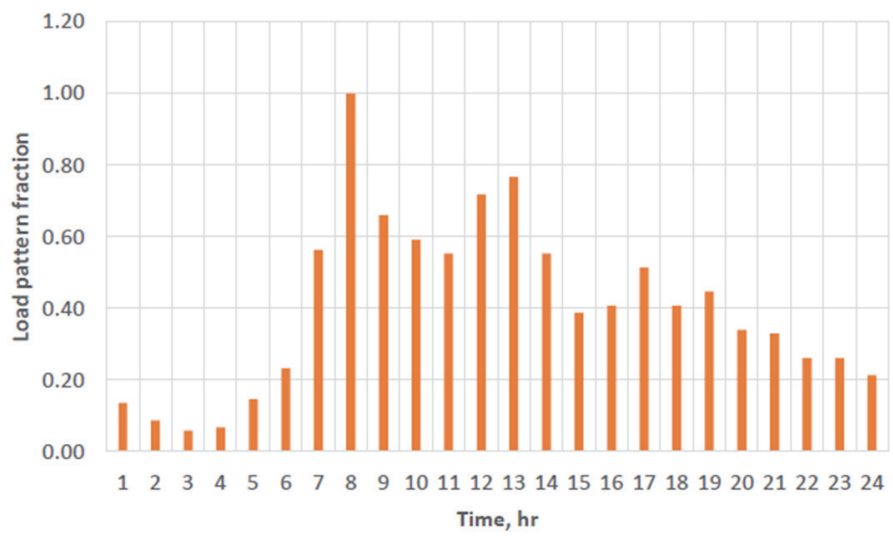

Figure 3. Typical hot water load pattern for Libyan families in Tripoli [31]

\section{Simulation Results}

In this section, a detailed discussion of each building will be presented in order to understand the behavior of each building from an energy consumption point of view. That will be done by focusing on the main energy consumption categories, their values, shares, and peaks. Then a comparison between the results of the three selected buildings will be presented.

\section{Building No. 1: Single Story Apartment}

The five major energy-consuming categories are cooling, heating, interior lighting, interior equipment, and water heating. Figure 4 presents those categories for building No. 1 as monthly consumed values in $\mathrm{kWh}$. During winter, the highest demand for heating was predicted during the month of January with $13 \%$ of the load. In terms of the total annual energy consumption, the share of the heating load is almost 3.5\%. On the other hand, during the cooling season, the cooling load represents a sizable share of energy consumption reaching almost $40 \%$ during July. The cooling load represents $18.7 \%$ of the annual energy consumed in building No.1.

July resulted in the highest total energy demand, which can be attributed to the high cooling load, almost $40 \%$, for this particular month. According to the results, the space cooling process effectively starts in March with a peak demand in July with a monthly value of $604 \mathrm{kWh}$ and ends in November. However, cooling demand in November has an insignificant load. The space heating process effectively starts in December and ends in April with a monthly peak of $143 \mathrm{kWh}$ in January. Space cooling season is longer than space heating season with an annual demand of 2580 and $472 \mathrm{kWh}$, respectively.

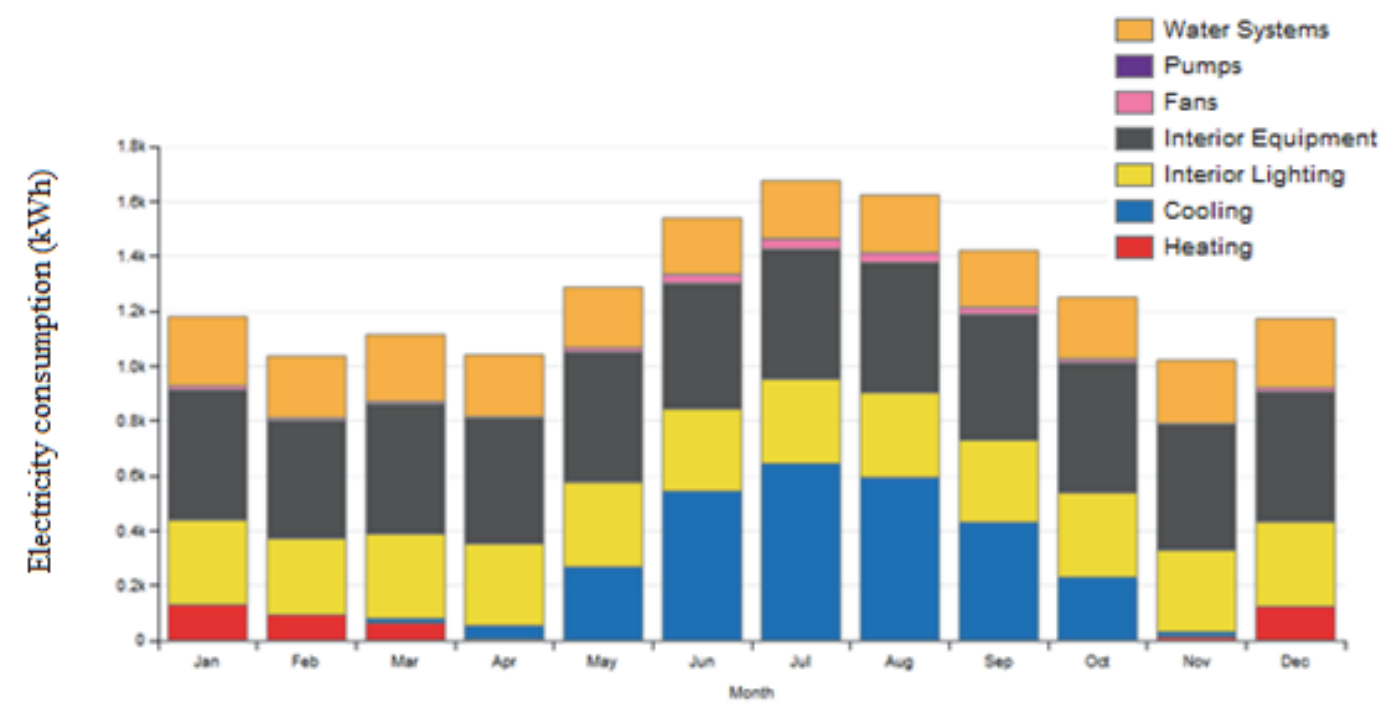

Figure 4. Electrical monthly energy-consumption throughout the year for building style No.1 
The amount of hot water consumption decreased during the summer and increased in the winter months. The water heating energy demand shows a small fluctuation across the year, with a minimum of $206 \mathrm{kWh}$ in June and a maximum of $252 \mathrm{kWh}$ in December and January, leading to an annual demand of $2710 \mathrm{kWh}$. This value represents about $19.6 \%$ of the total annual load. The share of the service hot water load varies from more than $20 \%$ during the winter season to $12 \%$ during the summer season. Since the required outlet water temperature is kept constant for the whole year, slight variations come from the variations in water mains feed temperature due to the season change.

The lowest values for lighting and equipment consumption was noted in February and were 175, and $429 \mathrm{kWh}$, respectively. Total lighting and equipment annual consumptions are estimated to be 2283 and $5595 \mathrm{kWh}$, respectively. These values represent $16.9 \%$, and $40.4 \%$ of the total annual energy consumption, respectively. The rest of the total energy consumption (less than $2 \%$ ) is attributed to miscellanies loads namely, fans and pumps.

\section{Building No. 2: Duplex House}

According to Figure 5, the space cooling process effectively starts in March and ends in November for the second building style. The peak demand occurs in July with a monthly value of $1714 \mathrm{kWh}$. The space heating process effectively starts in December and ends in April with a monthly peak of $486 \mathrm{kWh}$ in January. Space cooling season is longer than space heating season with an annual demand of 7479 and $1654 \mathrm{kWh}$, respectively. The cooling load represents a sizable share of the energy consumption, reaching almost $48 \%$ out of total monthly energy consumption during July, while the heating load accounts for $20 \%$ out of the energy consumption during January.

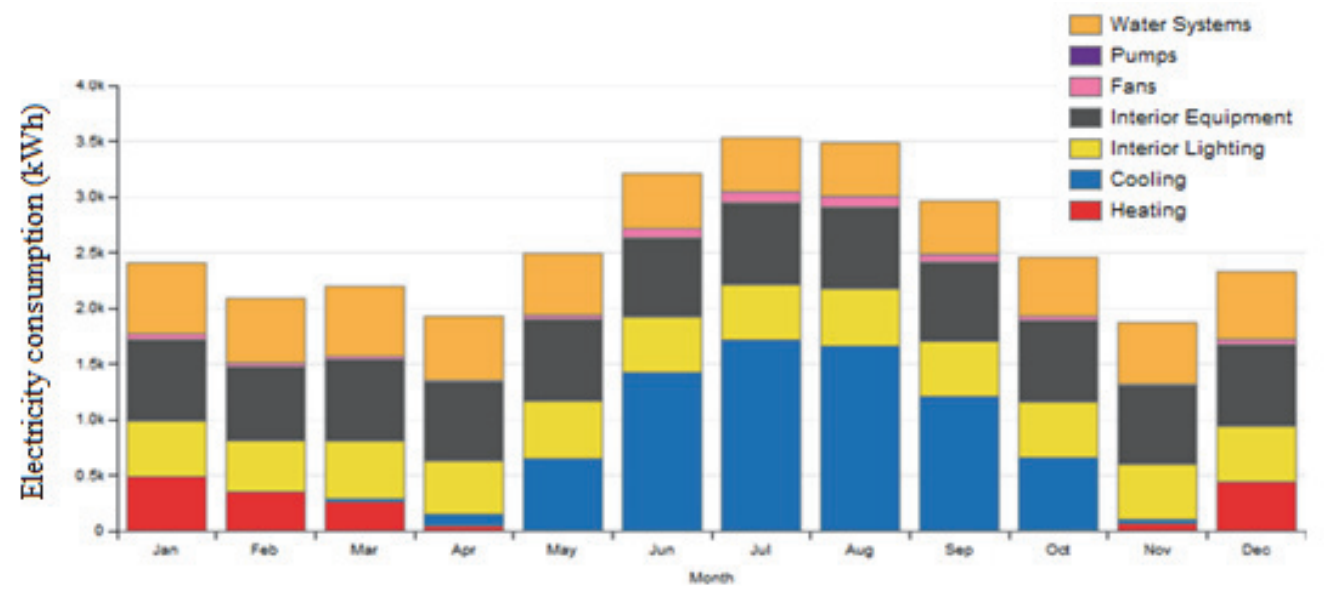

Figure 5. Electrical monthly energy-consumption throughout the year for building style No .2

Referring to the water heating system consumption, the values were found at the lowest value, $477 \mathrm{kWh}$ in September and the highest in January, $636 \mathrm{kWh}$. The water heating system represents $21 \%$ of the total annual energy consumption of building No.2. Regarding lighting and equipment, both consumption values are nearly constant. The lowest value for lighting and equipment is in February and is $457 \mathrm{kWh}$ and $644 \mathrm{kWh}$, respectively, with annual consumption of $19 \%(5955 \mathrm{kWh})$ and $28 \%(8659 \mathrm{kWh})$ of the total annual energy consumption, respectively.

\section{Building No. 3: Apartment}

The results obtained for building No. 3 are shown in Figure 6. Similar to the previous cases, the space cooling process starts in March with a peak demand in July with a value of $254 \mathrm{kWh}$ and ends in November. On the other hand, the space heating process starts in December and ends in April with a monthly peak of $82 \mathrm{kWh}$ in January. Annual space cooling demand is obviously higher than space heating demand with values of $1079 \mathrm{kWh}(8 \%)$ and $268 \mathrm{kWh}(2 \%)$, respectively.

The consumption of lighting and equipment are nearly constant. The lowest values for lighting and equipment were in February with 211, and $494 \mathrm{kWh}$, respectively. The total annual consumptions of lighting and equipment were estimated to be $2752 \mathrm{kWh}$ and $6048 \mathrm{kWh}$, which represent $21 \%$ and $45 \%$ of total annual energy consumption, respectively. 


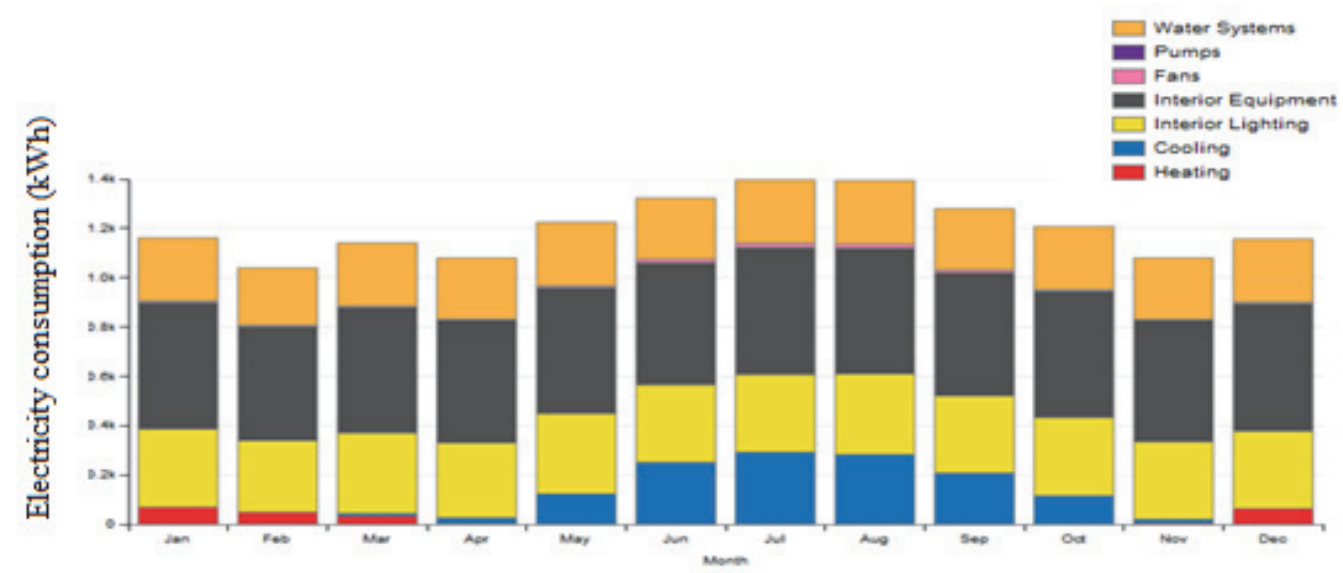

Figure 6. Electrical monthly energy-consumption throughout the year for building style No.3

For the water heating system, the lowest value of consumption occurs in February and is estimated to be $232 \mathrm{kWh}$ and reached a maximum value of $256 \mathrm{kWh}$ in December. The total annual consumption of the water heating system for building No. 3 is $3022 \mathrm{kWh}$, which represents $23 \%$ of the total annual energy consumption.

\section{Comparison of Building Styles}

Table 2 shows the different load categories for the three studied buildings. The interior equipment consumes the highest portion of energy in the three building styles, while the top four energy consumers are interior equipment, interior lighting, space cooling, and water heating. These four energy loads share $97 \%$ of the overall energy consumed in the third building, while they are $95 \%$ of the energy consumed in the second building style whereas, for the first building style, these four energy-consuming categories exploit $96 \%$ of the total annual energy consumption.

Table 2. Energy consumption throughout the year for three building styles.

\begin{tabular}{lccccc}
\hline \multicolumn{1}{c}{ End-Use } & $\begin{array}{c}\text { Building } 1 \\
(\mathrm{kWh})\end{array}$ & $\begin{array}{c}\text { Building } 2 \\
(\mathrm{kWh})\end{array}$ & $\begin{array}{c}\text { Building } 3 \\
(\mathrm{kWh})\end{array}$ & $\begin{array}{c}c \\
(\mathrm{kWh})\end{array}$ & $\%$ \\
\hline Heating & 472 & 1,656 & 268 & 799 & $4 \%$ \\
Cooling & 2,580 & 7,481 & 1,079 & 3713 & $19 \%$ \\
Interior Lighting & 2,283 & 5,956 & 2,752 & 3664 & $19 \%$ \\
Interior Equipment & 5,595 & 8,658 & 6,048 & 6767 & $35 \%$ \\
Fans & 203 & 597 & 92 & 297 & $2 \%$ \\
Water Systems & 2,710 & 6,608 & 3,022 & 4113 & $21 \%$ \\
Total & 13,845 & 30,957 & 13,262 & 19,355 & $100 \%$ \\
\hline
\end{tabular}

The annual energy consumption of the water heating system, equipment, and lighting in the second building style is higher than that consumed in the other building styles. This could be attributed to the existence of the two floors in the second building with the largest roof area and the highest number of occupants. The second building style showed similar results to the first building as indicated in Figure 5. Since the energy consumption by the interior lights and interior equipment do not vary with the ambient weather conditions, the domestic water heating load is dominant during the winter season while the cooling load is the dominant one during the summer season. Both cooling and heating are required during March, April, and November. This result may seem to be illogical, but it could be explained by the fact that the simulation EnergyPlus package predicts the cooling and heating loads according to the preset temperature range. It seems that during the afternoon cooling will be required while after midnight heating is required during the same month or even the same day under simulation. As expected in April and November, they have the minimum energy demand which is due to the low cooling and heating requirements.

For the third building style, July and August have the same total energy consumption at a value of $1375 \mathrm{kWh}$, which is the highest throughout the year. Once again, apart from the interior lights and interior equipment, which 
are characterized by fixed daily values, cooling is the dominant category during the summer season while heating is the dominant one during the winter season. On the other hand, service hot water contributes almost one-fifth of the annual energy demand. The low share of cooling and heating, as compared to water heating, is mainly due to the position of the third building style. This building is an apartment on the second floor of a high-rise building with windows in the North facing wall only. The spaces above and below the flat were assumed to be airconditioned and, therefore, the above and below surfaces are considered adiabatic surfaces in the simulation.

Referring to the results presented in Table 2, interior equipment energy consumption represents the highest annual demand of 5595,8659 , and $6048 \mathrm{kWh} /$ year for the $1^{\text {st }}, 2^{\text {nd }}$, and $3^{\text {rd }}$ building styles, respectively. Space heating energy demand represents only a fraction from the space cooling demand with 15 to $22 \%$ for the three styles. This confirms that space cooling is one of the main energy consumers in local residential buildings that reach a quarter of the total annual energy consumption. As a general energy benchmark, the water systems, space cooling, plus interior lights consume $60 \%$ of the energy requirements with a mostly equal share for each, while the equipment only has a high share of $35 \%$ of the total, leaving $5 \%$ for the rest items.

Table 3 shows the annual energy consumption for each building in four different units: total consumption, consumption per meter square, and consumption per meter square per person. It also shows the average values for those categories. The obtained results in the three buildings have been compared with the values of consumption in the United States where the energy consumption per square meter $143.5 \mathrm{kWh} / \mathrm{m}^{2}$ [14], which is higher than the presented values in table 3 . That is due to many factors including the site, orientation, weather conditions, envelope characteristics, and people's lifestyle.

Table 3. Annual consumption for each building per meter square and capita.

\begin{tabular}{llcccc}
\hline \multirow{2}{*}{ Load } & Area, $\mathrm{m}^{2}$ & 153 & 391 & 191 & Average \\
& People & 5 & 6 & 7 & \\
\hline $\mathrm{kWh}$ & & 13,845 & 30,957 & 13,262 & \\
$\mathrm{kWh} / \mathrm{p}$ & 2,769 & 5,160 & 1,895 & 3,274 \\
$\mathrm{kWh} / \mathrm{m}^{2}$ & 90 & 79 & 69 & 80 \\
$\mathrm{kWh} / \mathrm{m}^{2} / \mathrm{p}$ & 18 & 13 & 10 & 14 \\
\hline
\end{tabular}

\section{Conclusions}

Based on the above results, water heating systems account for almost one-fifth of the annual energy consumption for the studied buildings. During the winter season, the water heating systems are the dominant energy consumer, while in the summer season, the cooling load is the dominating consumer. July has the highest energy consumption, while April and November have the lowest amounts of energy consumption for the buildings. For the three buildings, the maximum power load occurs during the summer season where the cooling load is the dominant consumer. The double-floor building has a double energy consumption per meter squared, while its consumption per person is nearly triple compared to that of the flats. As a general energy benchmark, the water systems, space cooling, plus interior lights consume $60 \%$ of the energy requirements with a mostly equal share for each, while the equipment has the maximum share of $35 \%$ of the total, leaving $5 \%$ for the rest items.

\section{References}

[1] National Academy of Sciences, National Academy of Engineering, National Research Council. Real Prospects for Energy Efficiency in the United States. Washington, DC: The National Academies Press; 2010. https://doi.org/10.17226/12621

[2] Alghoul, S., Agha, K., Zgalei, A., \& Dekam, E. (2018). Energy Saving Measures of Residential Buildings in North Africa. Review and Gap Analysis, 7, 2018.

[3] Eskin, N., \& Türkmen, H. (2008). Analysis of annual heating and cooling energy requirements for office buildings in different climates in Turkey. Energy Build, 40, 763-73. https://doi.org/10.1016/j.enbuild.2007.05.008.

[4] United Nations (2015). Department of Economics and Social Affairs. 
[5] Crawley D, Lawrie L, Winkelmann F, Buhl W, Huang Y, Pedersen C, et al. (2001). EnergyPlus: creating a newgeneration building energy simulation program. Energy Build, 33, 319-331. https://doi.org /0.1016/ S0378-7788(00)00114-6.

[6] Hu, J., Kwong, P., \& Chao, C. (2007). Energy saving study in a hotel HVAC system. 6th Int Conf Indoor Air Qual Vent Energy Conserv Build Sustain Built Environ IAQVEC 2007, Oct 28, 2007 - Oct 31, 2, 91-98.

[7] Alghoul, S. A. (2017). Comparative Study of Energy Consumption for Residential HVAC Systems Using EnergyPlus. Am J Mech Ind Eng., 2, 98-103. https://doi.org/10.11648/j.ajmie.20170202.16

[8] Shahran, A., Reba, D., \& Krklješ, M. (2017). Thermal comfort, adaptability and sustainability of vernacular single family houses in Libya. Teh Vjesn - Tech Gaz., 24. https://doi.org/10.17559/TV-20160412221515

[9] Alghoul, S., Gwesha, A., \& Naas, A. (2016). The Effect of Electricity Price on Saving Energy Transmitted from External Building Walls. Energy Res J., 7, 1-9. https://doi.org/10.3844/erjsp.2016.1.9

[10] Umbarek, M. (2018). Estimation of Energy Consumption Benchmarks for Buildings. University of Tripoli.

[11] Hong, T. (2014). New Model to Simulate Energy Performance of VRF Systems. ASHRAE Summer Conf:18.

[12] Hendron, R., Anderson, R., Christensen, C., Eastment, M., \& Reeves, P. (2004). Development of an Energy Savings Benchmark for All Residential End-Uses. Natl. Renew. Energy Lab.

[13] Abdunnabi, M. (2012). Optimum values of tank volume to collector area ratios of thermosyphon solar water heaters for Libyan families. Sol Energy Sustain Dev., 1, 25-31.

[14] Shabunko, V., Lim, C., Brahim, S., \& Mathew, S. (2014). Developing building benchmarking for Brunei Darussalam. Energy Build, 85, 79-85. https://doi.org/10.1016/j.enbuild.2014.08.047

\section{Copyrights}

Copyright for this article is retained by the author(s), with first publication rights granted to the journal.

This is an open-access article distributed under the terms and conditions of the Creative Commons Attribution license (http://creativecommons.org/licenses/by/4.0/). 